\title{
A megfigyelés és megfigyeltség szubjektív aspektusai
}

\section{HÉDER Klára ${ }^{1}$}

\begin{abstract}
A "megfigyelés társadalmában" (surveillace society) a szisztematikus, strukturált adatgyűjtés lehetőségének bővülése megváltoztathatja az érintetti hozzáállást és a megfigyelés szubjektiv megélését is. A tanulmány a megfigyelői és megfigyelti oldal a megfigyeléssel kapcsolatos szubjektív aspektusaival, illetve a két szerep közti oszcilláció okozta percepcióváltás előzményeivel, érzelmi kérdéseivel és hatásaival foglalkozik.
\end{abstract}

Kulcsszavak: információs társadalom, megfigyelés, megfigyeltség, szubjektív megélés

\section{Előszó}

A cikk első szakaszában állambiztonsági dokumentumok segítségével bemutatja a hozzájárulás nélküli, diktatórikus, szisztematikus megfigyelés - döntően negatív - érzelmi következményeit és hosszan tartó viselkedésmódosító hatásait, a „megfigyeltség érzésének” szubjektív aspektusait, rövid és hosszú távú következményeit, mind a megfigyelői, mind pedig a megfigyelti oldalon. A második szakaszban pedig azokról a személyes tényezőkről, emocionális hatásokról, attitúdökről és tapasztalatokról esik szó, amelyek hozzájárulnak a megfigyelöi szerep felvételéhez, kiemelten érintve az „állampolgári újságírás” („,civil journalism”) és az erre adott rendőri reakciók kérdését.

A „megfigyelés” mint cselekvés vagy fogalom rendkívül széles tartalmi spektrumot lefedő konstruktum, ${ }^{2}$ amely a hétköznapi értelemben vett fókuszált figyelemtől, a tudományos kutatási módszeren át, a célzott adatgyưjtésig, nemzetbiztonsági ellenőrzésig rendkívül sokféle területet és megközelítést magában foglal.

A megfigyelés/információgyứjtés módszerei sem kevésbé változatosak, legyenek azok járókelők által készített telefonfelvételek, titkos operatív módszerek, vagy

Héder Klára pszichológus, doktori hallgató, Nemzeti Közszolgálati Egyetem Rendészettudományi Doktori Iskola.

Klára Héder psychologist, PhD student, University of Public Service Doctoral School of Police Sciences and Law Enforcement.

E-mail: hederklara@gmail.com, ORCID: https://orcid.org/0000-0002-0667-2305

2 Héder Klára: „Figyelés vagy megfigyelés?” egy fogalom konceptualizációs kérdései. In Baráth Noémi Emőke - Mezei József (szerk.): Rendészet-tudomány-aktualitások: A rendészettudomány a fiatal kutatók szemével. Konferenciakötet. Budapest, Doktoranduszok Országos Szövetsége Rendészettudományi Osztály, 2019. 115-125. 
az Európai Parlament és a Tanács (EU) 2016/679 Rendelete (GDPR ${ }^{3}$ ) szerinti adatkezelési múveletek.

Ez az írás azonban egyikröl sem szól.

A vizsgálni kívánt problémakör célkeresztjében nem a megfigyelés módja, annak célja, vagy a megfigyeléssel/adatgyüjtéssel szerzett információ feldolgozása és felhasználása áll, hanem a megfigyelés tényének vagy lehetőségének szubjektív megélése.

Ezért kérdésünk szempontjából mindegy, hogy az adatgyűjtés miért és hogyan történt. Nem az a fontos, hogy magán-, közbiztonsági, nemzetbiztonsági vagy hírszerzéshez kapcsolódó célból történt megfigyelés. Nem jelent különbséget, hogy az információszerzés módja telefonos lehallgatás, drónnal készített légi felvétel, arcfelismerő kamerák által gyưjtött adat, online tevékenységet monitorozó dataveillance vagy a katonai, titkosszolgálati és rendvédelmi operatív módszerek egyike, esetleg a digitális korszak ezer technikai lehetősége által nyújtott megfigyelési/adatgyújtési lehetőség valamelyike, vagy bármely más megfigyelési/adatgyűjtési módszer. A jelen cikk azt vizsgálja, mit gondol vagy érez mindevvel kapcsolatban a megfigyelést végző, vagy maga a megfigyelt.

E cikk tárgya annak a helyzetnek az érzelmi és kognitív hatása, hogy valaki - okkal, vagy éppen ok nélkül - úgy érzi, hogy ôt valaki/valakik, valamilyen módon megfigyelik, róla adatot gyüjtenek, felvételt készítenek, tevékenységét követik, értékelik, monitorizálják.

Másik kérdéskörünk pedig az, hogy milyen kognitív vagy érzelmi hatások, szubjektív tényezók vezethetnek ahhoz, hogy valaki megfigyelői szerepet vegyen fel, és hogyan reagálnak minderre a hirtelen megfigyelti pozícióba kerülő személyek, kiemelten a rendőrök.

A fenti két nagy kérdésre a választ a jelen írás - két látszólag össze nem illő szakaszban - annak a hipotézisnek az alapján keresi, hogy az információs társadalomban a megfigyelői és megfigyelti szerepek átjárhatóvá, felcserélhetővé, illetve párhuzamosan is megjelenővé váltak.

E tétel bizonyítására, előzményként - a rövid bevezető után - az 1950-60-as évek állambiztonsági dokumentumainak felhasználásával az e szerepek közti átjárhatóság megjelenési formáit, jeleit, valamint a megfigyelőkben és megfigyeltekben kialakuló kognitív és érzelmi hatásokat, közös elemeket, a kialakuló szubjektív perspektívákat mutatjuk be.

Az írás második szakaszában a megfigyelői/megfigyelti szerepek felcserélhetőségét, a szerepek közti váltás lehetőségét már bizonyítottnak (alapos indokkal feltételezhetőnek) tekintve, azt vizsgáljuk, hogy milyen szubjektív érzelmi és egyéb hatások vezethetnek oda, hogy civilek megfigyelöi szerepet vegyenek fel, s milyen hatást vált ki a „civil journalism” jelensége az érintettekből.

3 www.gdpr.info.hu/gdpr-rendelet-szovege 


\section{Bevezetés}

2021. január 28-án, az utazók előzetes tájékoztatása után, a Budapesti Közlekedési Központ 30 kamerával tesztüzemmódban megkezdte a jegyellenőrzés testkamerával való felvételét, a budapesti jegyellenőri munka rögzítését. ${ }^{4}$ A szerző ugyanaznap, az esti időszakban egy számára szokatlan lefolyású eseménynek lehetett a szemtanúja a 4-es villamoson.

Egy 5-6 főből álló jegyellenőri csoport körülállt egy körülbelül 30 éves utasnőt, aki teli torokból - több nyomdafestéket nem tűrő kifejezés között - üvöltötte: „Követsz, te kutya?! Követsz?! Vegyél csak fel...! Vegyél! Attó’ még nem vagy ember, hogy órákig követsz!"

Nem is a bliccelő viselkedése volt különös, hiszen sem a káromkodás, sem a kiabálás nem szokatlan esemény egy ellenálló személy részéről. A helyzet különlegességét az adta, ahogy a jegyellenőrök viselkedtek: némán körülállták a bliccelőt, és semmilyen akciót nem kezdeményeztek azon kívül, hogy nem engedték leszállni a járműről, amíg megjön a rendőrség. „Mindent vesz a kamera. Mindent” - mondták, és csak nézték az utast.

A szituációban azonban nemcsak a jegyellenőrök mutattak a megszokottól eltérő viselkedést, hanem az utazók is némileg furcsán reagáltak. A tömeg láthatóan próbált felvételen kívüli távolságba kerülni az intézkedőktől, fizikailag is jelentős távolságot tartva, az egyébként némán várakozó jegyellenőri csoporttól. A bliccelő utas egyre dühösebb ordítása mellett, az utasok kínos feszengése és a testkamera felvételekkel kapcsolatos aggódó megjegyzései, valamint a szinte hátborzongatóan nyugodt és magabiztos jegyellenőri magatartás adott keretet az intézkedésnek.

Úgy tűnt, hogy még szokatlan jelenségként, a jól látható helyen megjelenő testkamera, illetve a felvétel lehetősége, új elemekkel bővítette a résztvevők szereprepertoárját: az „ellenőr”, a „bliccelő” és az „utas” szerep mellett megjelent a „megfigyelö/ rögzítést végző” és a „megfigyelt/filmre vett” szerep is. A kamera jelenlétében a résztvevők módosítottak eddigi megszokott viselkedésükön, és ennek következményeként a megfigyelés/digitális adatrögzítés lehetősége megváltoztatta a benne részt vevők szerepét, érzéseit, viselkedését, és így magát a megfigyelt esemény lefolyását is.

Ha pedig néhány kamera ilyen jelentős hatással bír egy esemény alakulására, vagy az érintettek viselkedésére, akkor jogosan merül fel a kérdés: vajon milyen átfogóbb

\footnotetext{
Magyarországon a testkamerák bevezetése már más biztonsági, rendvédelmi területen sikeresen megtörtént, lásd pl. határőrség, Balla József: Integritási kockázatok csökkentése a határrendészek körében. Integritás tanulmányok 10. Budapest, Nemzeti Közszolgálati Egyetem, 2019; MÁV, Erdeiné Késmárki-Gally Szilvia - Erdei Attila - Grotte Judit: A biztonság szerepe a kötöttpályás közösségi közlekedésben, Budapest agglomerációjában. Belügyi Szemle, 68. (2020), 11. 89-104. mezőőrök, Országgyülési Őrség: Adatkezelési tájékoztató az Országgyúlési Ôrség által alkalmazott testkamerával megvalósuló adatkezelési tevékenységról. é. n. stb.
} 
hatásokkal számolhatunk a 21. század felügyeleti társadalmában (surveillace society ${ }^{5}$ ) ahol a megfigyelés/adatgyújtés már mindennapjaink kitörölhetetlen részévé vált, és ahol mi magunk is egyaránt vagyunk megfigyelők és megfigyeltek, adatgyüjtők és adatgyưjtések alanyai.

\subsection{Megfigyelöi-megfigyelti szerepváltás}

Néhány korban vagy politikai berendezkedésben az állampolgárok megfigyelésének gyakorlata olyan széles körűvé válik, hogy a társadalom többsége érintettnek érzi magát a kérdésben. Míg azonban a totalitárius diktatúrákban a megfigyelés „megrendelője” ismert, a végrehajtásért felelős szervezetek szerepe tisztázott, és lényegében csak a megfigyelt személye kérdéses, addig az információs társadalmak által nyújtott digitális technikák vadonatúj adatgyújtési, megfigyelési (surveillance) ${ }^{6}$ lehetőségei diverzifikálják a megfigyelési lehetőségeket, s kitágítják a megfigyelők és megfigyeltek körét is.

Sok jel mutat arra, hogy a „megfigyelés társadalmában” vagy másnéven a „felügyeleti társadalomban" (surveillace society) az eddig meglehetősen élesen elkülönült megfigyelői és megfigyelti szerepek átjárhatóvá, felcserélhetővé, változtathatóvá és egymás mellett élővé válnak, és a megfigyelő más szerepkörben maga is a megfigyelés/adatgyűjtés alanya lehet.

Így például az a hivatalos személy, aki munkaidejében rendőrségi nyomozáshoz gyűjt nyilvánosan elérhető adatokat a nyílt forrású információszerzés (OSINT) ${ }^{7}$ módszereivel, vagy végez operatív megfigyelési feladatokat, magánemberként szintén tárgya lehet valamilyen megfigyelésnek, adatgyüjtésnek. Az az emberierőforrás-szakember, aki napja egy részét a felvételre váró interjúalanyok szociális médiában megjelent adatainak összegyújtésével és profilozásával, a jelöltek aktivitásának megfigye-

A „megfigyelő társadalom”, vagy „megfigyelés társadalma” olyan társadalom, amelyet megfigyelésen alapuló technikák segítségével szerveznek és strukturálnak („The surveillance society is a society which is organised and structured using surveillancebased techniques."). David Murakami Wood - Kristie Ball (eds.): A Report on the surveillance society. Summary Report, Wilmslow, Office of the Information Commissioner, 2006. 2., valamint ahol a megfigyelési technológiákat széles körben használják az emberek mindennapi tevékenységeinek figyelemmel kísérésére. David Lyon: The electronic eye: The rise of surveillance society. University of Minnesota Press, 1994.

6 David Lyon: Surveillance studies: An overview. Cambridge, UK, Polity, 2007. A surveillance definíciója Lyon szerint: „The focused, systematic and routine attention to personal details for purposes of influence, management, protection or direction.” Lyon (2007) i. m. 14. Az angol „surveillance” kifejezés magyarul többféleképpen fordítható. Jelen írásban kontextustól függően „megfigyelés”-ként vagy „felügyelet”-ként fordítjuk, illetve a „surveillance” fogalom által fedett fogalomkört és tartalmi hálót használjuk a „megfigyelés” és „megfigyelt” (személy) megnevezésekor.

7 Lévay (2006) Open Source Intelligence definíciója: OSINT „A katonai felderítés és hírszerzés rendszerén kívül létező, a publikum (tehát minden egyén) számára nyilvánosan, legális eszközökkel megszerezhető, vagy korlátozott körben terjesztett, de nem minősített adatok szakmai szempontok alapján történő felkutatását, gyűjtését, szelektálását, elemzését-értékelését és felhasználását jelenti." Lévay Gábor: OSINT (Open Source Intelligence) - Nyílt információs hírszerzés. Budapest, Zrínyi Miklós Nemzetvédelmi Egyetem, 2006. 6. 
lésével és elemzésével tölti, kilépve munkahelye ajtaján a CCTV-k ${ }^{8}$ által megfigyelt járókelővé, vagy éppen digitális lábnyomán keresztül nagyvállalatok adatbányászati érdeklődésének tárgyává válhat.

Így míg korábban a megfigyelői/megfigyelti szerepek élesen elkülönültek, valamely foglalkozáshoz (például rendőr), korhoz (például idősek) vagy megadott funkciókhoz (például őrszem) kötődtek, addig az információs társadalom polgárai szerepeiket rugalmasan váltják, vagy akár éppen egyszerre is betölthetik mindkét pozíciót. A rugalmas megfigyelői/megfigyelti szerepváltás/szerepfelvétel a digitális korban az élet minden területén megjelenik. Például a munkahelyén valamely adatgyújtést folytató - megfigyelői/adatgyűjtői szerepben dolgozó - munkatárs viselkedését a munkaadó informatikusa bármikor ellenőrizheti (így ezzel megfigyelői munkájával párhuzamosan megfigyelti szerepbe is juttatva őt). De hasonló gyors váltás figyelhető meg egy köztéri eseményt mobiljával felvevő járókelő esetében is, aki a felvétel elindításával felveszi a megfigyelő szerepet, miközben tudja, hogy a térfigyelő kamerák az ő viselkedését is rögzítik.

A fent leírt bliccelési helyzetben ugyan az utasok - valószínúleg a helyzet szokatlansága miatt - nem kapták elő telefonjaikat, hogy rögzítsék a „botrányos” eseményeket, de ahogy azt sok más intézkedési helyzet megmutatta, ${ }^{9}$ némely esetben a jelenlévők valóban szerepet váltanak és a megfigyelt/a filmfelvétel alanyát képező személyből megfigyelővé, rögzítővé is válhatnak, és később a készült felvételeket meg is osztják a nagy nyilvánossággal.

Jelen írás azt a feltételezést járja körül, hogy

a 21. század digitális környezetében a megfigyelöi, illetve megfigyelti pozíció plauzibilis átjárhatóságot mutat: egy személy lehet megfigyelt és megfigyelő is.

$\mathrm{Az}$, hogy ki melyik szereppel azonosul, vagyis magát az adott pillanatban megfigyeltnek vagy megfigyelőnek látja, sokféle érzelmi és kognitív hatás, szubjektív aspektus eredőjeként alakul ki.

Az eltérő szerepekkel való identifikáció pedig egyaránt hathat az adott helyzet értelmezésére, a szituációval kapcsolatos érzelmi reakciókra, valamint a tényleges viselkedésre is: vagyis megváltoztathatja az érintetti hozzáállást, a megfigyelés, a megfigyeltté válás, a megfigyeltség szubjektív megélését, és ennek következményeként a percipiált helyzetre adott válaszreakciót is.

A következő szakasz elsőként - mintegy előzményként - a „hagyományos” (például nemzetbiztonsági) megfigyelés szubjektív megfigyelői/megfigyelti megélését tekinti át,

Pl. térfigyelő kamerák. A CCTV-kamerarendszer (Closed-circuit Television) zárt láncú biztonsági kamerákat összekapcsoló megfigyelőrendszer, ahol felvételek monitoron/TV-n nézhetők vissza az arra jogosultak által, anélkül, hogy külső szemlélő hozzáférhetne a felvett tartalomhoz.

9 Mint például a Rodney King vagy pedig George Floyd elleni rendőri intézkedés esetében készült állampolgári filmfelvétel és közösségi megosztás esetén. A járókelők rendőrségi intézkedésekről készülő felvételeiről és az ezekkel kapcsolatos aggályokról a cikk második felében esik majd részletesen szó. 
néhány korabeli dokumentumból idézett részlet felhasználásával, bemutatva a megfigyelői és megfigyelti szerepek közti modernkori átmenet előzményeit, érzelmi hatásait; majd a digitális korszak megfigyelői/megfigyelti szerepváltásának rendészeti hatásait tárgyaljuk, a „sousveillance” és a „civil journalism” jelenségek rendvédelmi vonatkozásainak megbeszélésével.

\section{Megfigyelöi/megfigyelti szerepelmosódás: ellenőrzés és az ellenörzöttség (érzése)}

Bár a megfigyelői/megfigyelti szerep váltása a digitális korszakban vált kifejezetten figyelembeveendő tényezôvé, maga a jelenség azonban korántsem új keletû. A diktatúrákban, totalitárius államokban az állampolgárok megfigyelésére kiépített rendszerek olajozott múködéséhez a „beépített bizalmatlanság”, a saját munkatársak állandó megfigyelése és ellenőrzése, a nem digitális állami „surveillance” is szervesen hozzátartozik.

A hivatásos megfigyelők többsége - tudtuk nélkül - valamilyen ellenőrzés, megfigyelés alatt állt maga is, hozzájárulva az élesen elkülönülni látszó megfigyelői/megfigyelti szerepek közti határ elmosódásához, átjárhatóbbá válásához.

\subsection{A megfigyelök megfigyelése}

Egy, a Belügyminisztériumban 1971-ben készült, és a titkos hálózati munka fontosabb kérdéseit tananyagszerủen tárgyaló, szigorúan titkos jegyzetben így fogalmaz - az egyébként meg nem nevezett - szerző az ügynökök ${ }^{10}$ kötelező ellenőrzéséről/megfigyeléséről:

„Az ügynökök rendszeres és alapos tanulmányozása, valamint ellenörzése a velük folytatott együttmúködés egész időtartama alatt kötelező feladat a hírszerző számára.

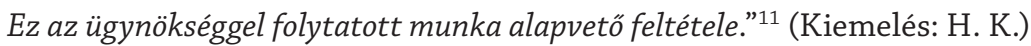

A tanulmány szerzője később részletesen indokolja is a megfigyelés okát, és gyakorlati tanácsokkal is ellátja a jegyzet olvasóit, hogy a feladatot milyen módon javasolja elvégezni:

„Az ügynök hírszerző lehetőségeinek helyes meghatározása érdekében szakadatlanul tanulmányozni kell [Kiemelés: H. K.] az ügynök helyzetét, ismerni a munkahelyén szerzett tekintélyét, tudni kell, hogyan vélekednek róla vezetői; milyen

\footnotetext{
10 Vagyis egy kifejezetten megfigyelést és adatgyüjtést végző csoport. ÁBTL 4.1. A-3114 - Az ügynökség vezetése és nevelése. Belügyminisztérium, III/I. Csoportfőnökség kiadványa, 1971.

11 ÁBTL 4.1. A-3114, 1971. 63.
} 
viszonyban van környezetével, mennyire férhet hozzá a hírszerzést érdeklő dokumentumokhoz és végre tudja-e hajtani a hírszerzés más feladatait. /Pl. utazások összekötőként vagy futárként stb./"12

„A provokátorok, kettős ügynökök és lelkiismeretlenül dolgozó ügynökök felderítése rendszerint az ellenörzés kombinált módszereivel történik." ${ }^{13}$ (Kiemelés: H. K.)

A fenti célok gyakorlatban történő megvalósulására példa két hálózati személy „fedett” összeismertetése, vagy olyan ellenőrző feladat adása az egymás szerepét nem ismerő ügynökök számára, amelyből viselkedésükre következtetni lehet, mint ahogy „Pázmándy” és „Váraljai” ügynök esetében történt 1960. június 21-én K. Gy. rendőr főhadnagy - a két ügynök közös tartótisztje - utasítására. Az eseményről „Váraljai” jelentése mögé a következő tartótiszti hozzáfűzés került:

„Értékelés: Az ügynök végrehajtotta a feladatát. A Sz.-al ${ }^{14}$ folytatott beszélgetés tárgyát ellenőrzésként határoztam meg. A jelentésből látszik, hogy mindkét ügynök betartotta a kapott feladatokat és nem nagyon nyilatkozott a viszonyáról. Ezt pozitívnak értékelem. A jelentések tartalma fedi egymást." ${ }^{15}$ (Kiemelés: H. K.)

A másik megfigyelő (ügynök) megfigyelésére/ellenőrzésére irányuló feladatokat természetszerúleg nem lehetett felfedni az érintett előtt. ${ }^{16}$ Vajon ez azt is jelentette, hogy az adott személy nem volt tisztában azzal, hogy esetleg ő maga is megfigyelés tárgya?

\subsection{A „megfigyeltség érzése”}

A jelek azt mutatják, hogy bár a pontos megfigyelés mikéntjéről és lebonyolításáról a legtöbb megfigyelt félnek nem volt tudomása, sokszor azonban - okkal vagy éppen ok nélkül, de - kialakult a „megfigyeltség, ellenőrzöttség” homályos érzete, illetve megjelentek az ezzel kapcsolatos negatív érzelmek (félelem, aggodalom, szorongás vagy akár pánik is). A jelenség olyan gyakorinak mondható, hogy még a hivatalos jegyzetben is esik róla néhány szó:

„[A]z ügynök, akit nemrég szerveztek be, minden lépésnél azt hiszi, hogy figyelik. Az ilyen ügynök könnyen pánikba esik és durva hiba elkövetésére képes." (Kiemelés: H. K.) ${ }^{17}$

\footnotetext{
ÁBTL 4.1. A-3114, 1971. 43.

13 ÁBTL 4.1. A-3114, 1971. 65. A jegyzet további részeiben a szerző mind a hagyományos, mind pedig a kombinált eszközöket is részletezi.

14 A név anonimizáció céljából rövidítve: $\mathrm{H}$. K.

15 ÁBTL - 3.1.2 - M-28500_1, részlet „Váraljai” fn. ügynök jelentéséből. 60.

16 „Természetesen titkolni kell az ellenôrzést végző ügynök elöl is, hogy egy másik ügynök ellenőrzéséről van szó." (Kiemelés: H. K.) ÁBTL 4.1. A-3114, 1971. 70.

17 ÁBTL 4.1. A-3114, 1971. 30.
} 
$\mathrm{Az}$ - nem tudjuk, hogy valós vagy megjátszott - aggodalom egy másik esetben, az „Orvos” fedőnevü ügynök esetében is olyan jelentős, hogy egyik - általa is megfigyelt - barátja így emlékszik vissza akkori viselkedésére:

„Mindenki tudta, hogy proletárdiktatúra, ÁVÓ, terror. Hát olyannyira, hogy a V. Laci, ${ }^{18}$ az öregem minden telefonja után azt mondta, hogy „Halló? Mindent felvettetek? Melyiket ismételjem meg? Biztos mindent felvettetek?" Letette."19

Egy olyan társadalomban, ahol a megfigyelés lehetősége dominánsan központosított, az érintettek, legyenek azok akár maguk is megfigyelők, többségükben úgy érzik, hogy lehetőségeik korlátozottak és igen korlátozott kontrollal rendelkeznek a megfigyelés megakadályozására. Az állandó megfigyeltség - vagy ennek érzése - pedig jelentős viselkedésmódosító hatással rendelkezik:

„Ha lehallgatnak, ha erről meggyőződtél, ha körülötted ez a szokás, akkor észlelheted magadon a fenti tényállásból következő kisded stratégiákat és elváltozásokat. Pucér vagy. Mindenkivel való beszéded együtt már plasztikus, testszerű, mert egyik a másikat helyesbíti-tagadja, s foglalja többdimenziós élő valóságba. A hűséges lehallgató előtt nyitott könyv az életed. [...] Mindig hárman vagyunk, akkor is, ha csak ketten lenni szeretnénk. Belóg a térbe egy láthatatlan mikrofon, bármikor kinyílik a szoba oldalt vagy felül, és látnak, hallanak. Velük vagyok, akkor is, ha egy szóval sem hívtam őket, és legföljebb kitépni tudom a készüléket a falból, padlóból, mennyezetből, mint valami undok gyomot. Ezt megtettem, de a gyom természete szerint újranő."20

Az állami megfigyelés jeleivel átszőtt társadalom tagjaiban hosszú távon megerősödni látszik a feltételezés, hogy „a falnak is füle van”, s mindenkit valamilyen figyelem övez.

„1999 őszén szóltam K.-nak, hogy segítsen, meg szeretném nézni az anyagaimat, ha vannak, a Történeti Hivatalban, hogy figyeltettek-e vagy lehallgattak-e annak idején; itt mindenki azt hiszi, hogy rá volt állítva a fél titokrendőrség..." 21

A bizonytalan, de rendkívül valószínú megfigyelés lehetősége, vagyis az a tudás, hogy a társadalomban a megfigyelés igen elterjedt, de arra vonatkozóan nincs biztos információ, hogy az adott személyt valóban megfigyelik-e, illetve nem lehet tudni, hogy ki szolgáltat adatokat az állami szerveknek, paranoid hangulatot eredményez:

\footnotetext{
18 A név anonimizáció céljából rövidítve: $\mathrm{H}$. K.

19 Kisfaludy András: Törvénytelen Muskátli. (dokumentumfilm) 1. rész, 1996. 30.22 - 30.38.

Konrád György: Ha lehallgatnak. ÉS publicisztika, (1998), 24. részlet.

1 Esterházy Péter: Javított kiadás - Melléklet a Harmonia Caelestishez. Budapest, Magvető, 2002. 5.
} 
„Másnap délelőtt beszélgetést folytattam, melyen jelen voltak [...]. Ennek során B. kifejtette, hogy fél, nehogy letartóztassák emiatt. Ekkor tréfásan a beszélgetés résztvevői egymást vádolták azzal, hogy a másik a besúgó." 22 (Kiemelés: H. K.)

Kialakul az az érzés, hogy a megfigyelés állandó, nem kikerülhető, a megfigyeltek ellen irányuló, személyre szabott és központosított. Ennek az érzésnek a hatása nemcsak azokat érinti, akiket a rendszer valóban ellenőriz. A végig megfigyelő szerepkörben lévők (például ügynökök, tartótisztek) is, akiknek - legalábbis elvileg nem lehet olyan információja, hogy őket is megfigyelték volna - gyakran küzdöttek ugyanezzel a homályos, behatárolhatatlan negatív érzéssel: azzal, hogy valaki, valahogy, „valahonnan” folyamatosan megfigyeli és ellenőrzi őket.

\subsubsection{A „megfigyeltség érzésének" rövid és hosszú távú hatásai}

A legfontosabb viselkedésmódosító tényező a nagyon valószínű, de nem bizonyított és nem bizonyítható megfigyelés lehetősége, a személyre szóló adatgyűjtés valószínưsége, jelentős negatív érzelmi hatásokkal jár. A - lehetséges - megfigyeltek úgy érzik, hogy életük feletti kontrolljuk csökkent, tetteik mindig láthatóvá, értékelhetővé váltak. Csökken a bizalom, csorbát szenved a személyközi intimitás, a kialakuló paranoid hangulatban olyan furcsa esetek eshetnek meg, mint amikor a megfigyelt a megfigyeléssel kapcsolatos taktikáiról éppen a jelentő ügynöknek számol be.

„Elmondja B., hogy félévben jelesen végzett és igyekszik, jól tanul, sokat gyakorol és zeneszerzéssel foglalkozik. Egyébként magányos életet él, mert fél a provokátoroktól és spionoktól, akik mindenkit bajba rántanak. Engem igen sajnál." ${ }^{23}$

A szisztematikus megfigyelés azonnali következményei mellett a kialakuló hosszú távú hatások sem elhanyagolhatók: az érintettek elhúzódó időintervallumban (jóval a tényleges megfigyelés után is) úgy gondolják, hogy továbbra is megfigyelés alatt állnak.

A fent említett „Orvos” fedőnevű ügynökkel több évvel aktív hálózati munkájának befejezése után esett meg a következő eset (amelyet szintén egy ügynöki jelentésből ismerhetünk meg):

„V. László mániája, hogy őt a rendőrség figyeli és lehallgatják a telefonját. Ezért - cukkolásképpen - éjszaka 2 felé /kb. 2 éve/ felhívtuk, nem mutatkoztunk be, és azt mondtuk, hogy legyen másnap 10-kor itt és itt, ahol egy férfi fogja várni, aki a többit majd elmondja. 5 perc múlva felhívtam, mert megsajnáltam, mennyire

22 Részlet az „Orvos” fedőnevű ügynök jelentéséből, ÁBTL, M-17764_2, 273., Az esemény ideje: 1961. okt. 24.; A név anonimizáció céljából rövidítve: $\mathrm{H}$. K.

23 Részlet az „Orvos” fedőnevű ügynök jelentéséből, ÁBTL, M-17764_2, 336., Jelentés ideje: 1962. márc. 20.; A név anonimizáció céljából rövidítve: H. K. 
megijedt, de fél órába telt, amíg elismerte a telefont és elhitte, hogy mi voltunk." ${ }^{24}$ (Kiemelés: H. K.)

A múlt rendszer egyik volt magas rangú nemzetbiztonsági tisztje, saját tapasztalatai alapján visszavonulásáról pedig így nyilatkozik:

„Senkivel nem tartom a kapcsolatot. Azért az ember azért azzal tisztában van, hogy az utolsó három-négy évemben egy jelentős pozíciót töltöttem be a Belügyminisztériumnál. Nem akármilyen területnek voltam az országos gazdája. Az egyházi területnek. Na, most azért bennem is felmerül az, hogy néha ellenöriznek." ${ }^{25}$ (Kiemelés: H. K.) ${ }^{26}$

Az idézetek alapján joggal feltételezhetjük, hogy a hozzájárulás nélküli, diktatórikus, szisztematikus megfigyelés mind a megfigyelői, mind pedig a megfigyelti oldalon hosszan tartó viselkedésmódosító és - negatív - érzelmi hatása döntően a kontroll érzésének csökkenése, paranoid gondolatok megjelenése, a személyközi kapcsolatokban és az élet egyéb területein érzett bizonytalanság, valamint a „megfigyeltség érzésének" hosszan tartó fennmaradása.

A különféle megfigyelői/megfigyelti szerepekhez kapcsolódó érzéseket és viselkedési stratégiákat természetesen a kor, a társadalmi berendezkedés és a megfigyelés aktusa maga is befolyásolja. Feltehetően több negatív érzés kapcsolódhat egy totalitárius állam „felülről-lefelé” (top-down) haladó surveillance jellegű megfigyelési stratégiáihoz, mint a digitális korszak sokkal demokratikusabb és horizontálisabb megfigyelési és adatgyưjtési lehetőséget nyújtó lehetőségeihez, de ilyen érzelmi hatások megjelenése napjainkban sem kizárható.

A következő szakasz az eddig szinte kizárólag csak megfigyelti szerepben lévő állampolgárok megfigyelői szerepvállalásának kérdését, a „bottom-up” megfigyelés hatásait és mindennek a rendőrségi munkával való kapcsolatát tárgyalja a digitális korban. ${ }^{27}$

\footnotetext{
24 ÁBTL - 3.1.2 - M-28327_1, „Bodo” fn. ügynök jelentése, 37. A tartótiszt megjegyzése: „A jelentés ellenőrzött, megtörtént tényt jelent az informátor." A név anonimizáció céljából rövidítve: $\mathrm{H}$. K.

25 Ács Péter. In Varga Ágota: A tartótiszt. (dokumentumfilm) 2013. 30.09-30.32 perc.

26 Ács Péter. In Varga Ágota: A tartótiszt. (dokumentumfilm) 2013. 30.09-30.32 perc.

27 A digitális surveillance „top-down” folyamataival kapcsolatos szubjektív aspektusok tárgyalása meghaladja jelent tanulmány kereteit, ezért a továbbiakban csak a modern társadalmak „bottom-up” folyamatait érintjük, kiemelt szerepet adva az állampolgárok megfigyelői és hírmegosztó viselkedésének a „civil journalism” jelenségének.
} 


\section{A megfigyelés kölcsönössége: „sousveillance” és a „citizen journalism"}

A modern nyugati társadalmakban a célzott megfigyelés - vagy más szóhasználattal felügyelet - („surveillance”) pervazivitása széles körben tárgyalt kérdéssé28 és összefüggő tudományos kutatási területté vált, mint „surveillance studies”. ${ }^{29}$ A felügyeleti technikák, az új informatikai lehetőségek, az egyre kisebb és könnyebben használható felvevőeszközök, valamint az elérhető, ingyenes videómegosztó oldalak robbanásszerű bővülésével az 1990-es évektől jelentősen megemelkedett a magánszemélyek által készített fotók, hírértékű felvételek száma és jelentősége. ${ }^{30}$ Megjelent és egyre jelentősebbé vált a „sousveillance”. ${ }^{31}$

A kifejezésben szereplő a „sous” francia szó jelentése „alul”, amely a szóösszetételben arra utal, hogy a surveillance felülről-lefelé („top-down”) folyamata helyett, itt az „alulról-felfelé haladó” („bottom-up”) múködés dominál: ${ }^{32}$ vagyis a surveillance centralizáltsága, hierarchizáltsága és dominánsan tervezett jellege helyett, a sousveillance esetében inkább az intézményesítettség hiánya, az alkalomszerúség, delokalizáltság és demokratikus jelleg, valamint a hatalmi egyensúlyhiány csökkentésére irányuló szándék jellemző: ${ }^{33}$ vagyis egyre több, addig csak megfigyelti szerepben lévő állampolgár kezdett maga is a hatalommal rendelkező szervezetek és munkatársaik akcióinak megfigyelésébe, különféle események rögzítésébe és megosztásába.

A „sousveillance”-t magyarul „ellenfigyelésnek”, „visszafigyelésnek” („reverse surveillance”) esetleg "alulról figyelésnek” is fordíthatjuk ${ }^{34}$ („surveillance from below”). Ez az inverz megfigyelés („inverse surveillance”) lényegében egy olyan állampolgári tevékenység, ahol az adott személy egy eseményről készít felvételt, amelyet mások számára is elérhetővé tesz, megoszt (legtöbbször az interneten). A sousveillance felvétel jellemzően hétköznapi, de valamiért figyelmet igénylő helyzetben történik: „boltosokat fényképező ügyfelek; utasok, akik taxisofőröket fotóznak; állampolgárok, akik az ajtajuk előtt álló rendőröket fényképezik, civilek, akik kormánytisztviselőket fotóznak; vagy helybéliek, akik müholdas felvételeket sugároznak a megszálló

28 David Lyon Surveillance Society: Monitoring everyday life. Buckingham, Open University Press, 2001.; Jay Stanley - Barry Steinhardt: Bigger monster, weaker chains: The growth of American surveillance society. Washington, Technology and Liberty Program, American Civil Liberties Union, 2003.

29 Pl. www.surveillance-studies.net

30 Marianne F. Kies: Policing the police: Freedom of the press, the right to privacy, and civilian recordings of police activity. The George Washington Law Review, 80. (2011), 1. 274-310.

31 Steve Mann - Jason Nolan - Barry Wellman: Sousveillance: Inventing and using wearable computing devices for data collection in surveillance environments. Surveillance \& Society, 1. (2003), 3. 331-355.

32 Frej Klem Thomsen: The concepts of surveillance and sousveillance: A critical analysis. Social Science Information, 58. (2019), 4. 701-713.

33 Jean-Gabriel Ganascia: The generalized sousveillance society. Social Science Information, 49. (2010), 3. 489-507.

34 Székely Iván: Surveillance - a megfigyeléstől a megfigyelő társadalmakig és a megfigyeléstudományig. Replika, 89. (2014), 5. 7-13. 
csapatokról az internetre”. ${ }^{35}$ Az ilyen jellegű felvételt készítők gyakran monitoroznak olyan hatalommal rendelkező szervezeteket és munkatársaikat, mint a rendőrség. ${ }^{36}$

A sousveillance napjainkra olyan elterjedté és jelentőssé vált, hogy már mérhető társadalmi hatása van annak, hogy hordozható készülékeikkel lényegében bárki lefotózhat bárkit, vagy rögzíthet bármely eseményt, amelyet felvételre érdemesnek talál, majd azt az interneten megoszthatja. A hordozható informatikai eszközök lehetővé tették a polgárok számára, hogy olyan történéseket dokumentáljanak, amelyek számukra fontosak, részt vegyenek az események alakításában; lényegében megfigyelői szerepet felvéve fordított felügyeletet gyakorolhassanak a mérvadó pozícióban lévő személyek felett. ${ }^{37}$

Az ilyen állampolgári viselkedésben egyaránt megfigyelhető az események dokumentálásra, megosztására és valamilyen újfajta - a polgárok szempontjából kiegyensúlyozottabb - hatalmi egyensúlyt megteremtésére irányuló szándék. A jelenség elterjedésének és jelentőségének növekedésével Ganascia pedig egyenesen generalizált „sousveillance society”-ről beszél, ${ }^{38}$ amelyben a megfigyelés minden résztvevő által tömegesen gyakorolt tevékenységgé vált.

\subsection{Az érzelmi érintettség mint szerepváltó tényezö: civilek és a „citizen journalism”}

Ha pedig már elég sokan képesek, hajlandóak és eltökéltek arra, hogy megörökítsék a köröttük zajló eseményeket, majd ezeket publikussá tegyék, akkor megjelenik a sousveillance különleges formája a „citizen journalism” ${ }^{39}$ jelensége, amely Örnebring frappáns meghatározása szerint amatőrök által szolgáltatott hírek („news produced by amateurs" ${ }^{\prime 0}$ ).

A rendőri intézkedések pedig szinte mindig hírértéket képviselnek, s így ezek az események joggal tarthatnak igényt a civil hírmegosztók és hírfogyasztók érdeklődésére.

A hírérték azonban nem tekinthető elégséges motívumnak arra, hogy egy rendőri intézkedést igénylő éles helyzetben, egy, a szituációban valójában nem érintett személy felvételt kezdeményezzen, s ezzel felvegye a megfigyelői szerepet.

Joggal merül fel a kérdés, a hírértéken kívül mi egyéb motiválja az adott járókelőt, hogy ilyen drasztikus lépést tegyen? Miért kerül előtérbe egy sokszor aggasztó vagy

\footnotetext{
Mann-Nolan-Wellman (2003) i. m. 333.

36 Alice E. Marwick: The public domain: Social surveillance in everyday life. Surveillance \& Society, 9. (2012), 4. 378-393.

Mann-Nolan-Wellman (2003) i. m. 2003.

Ganascia (2010) i. m. 489-507.

39 Serena Miller: Citizen journalism. In Michael Karlsson et alii (eds.): Oxford research encyclopedia of communication. New York, Oxford University Press, 2019. 1-25.

40 Henrik Örnebring: Anything you can do, I can do better? Professional journalism on citizen journalism in six European countries. International Communication Gazette, 75. (2013), 1. 36.
} 
akár veszélyes helyzetben az, hogy megfigyelőként és később tartalommegosztóként dokumentálja az adott eseményt?

Egy, a kérdéskörben végzett kutatás ${ }^{41}$ eredményei alapján úgy tűnik, hogy a felvételek növekedésében egyaránt szerepet játszik az eszközök elérhetősége (accessibility of devices), az elszámoltathatóság iránti igény (desire for accountability), a nem megfelelő intézkedés megelőzésének célja (preventing misconduct), valamint a passzív ellenállás szándéka (passive resistance) is. Kimutatható hatást gyakoroltak ezenfelül a felvételi hajlandóságra az adott állampolgár rendőrsséggel kapcsolatos korábbi személyes és közvetett - föként rossz - tapasztalatai is. ${ }^{42} \mathrm{Az}$ eredmények alapján azok az egyetemisták, akik úgy gondolták, hogy a rendőrségi intézkedések felvételével és megosztásával előmozdítják a társadalmi igazságosságot (social justice), és megelőző hatással vannak a nem törvényes rendőri intézkedések kialakulására, nagyobb szándékot mutattak a rendőri intézkedések lefilmezésére. Szintén növelte a rögzítési szándékot, hogyha valaki úgy gondolta, hogy a felvétel megvédi a rendőri intézkedés eldurvulásától (mintegy hatóság elleni „önvédelem”-ként), valamely etnikai minoritáshoz tartozott, az elmúlt három évben már készített hasonló felvételt, és/vagy ha már volt előzetesen rossz tapasztalata a rendőrséggel, akár saját maga, akár valamely ismerőse révén.

Összességében úgy tűnik, hogy a rendőrséggel kapcsolatos rossz érzések és félelmek, olyan előzetes negatív tapasztalatok, mint az erőszak indokolatlan alkalmazása, nemi, faji diszkrimináció megtapasztalása előmozdítják, hogy a helyzetben tevékenyen nem érintett személyek megfigyelői pozíciót vegyenek fel, s így fokozzák percipiált kontrolljukat az adott helyzetben.

\subsection{A sousveillance rendöri szemmel}

A legtöbb sousveillance felvételt - így a rendőri intézkedésekről készült filmfelvételeket is - közterületeken készítik. A felvételek többsége valamilyen furcsa, szokatlan vagy éppen az adott személy/közösség számára ijesztő, félelmetes, esetleg elfogadhatatlan eseményt dokumentál, legtöbbször már a közösségi megosztás előzetes szándékával. Az egyéni szögből, gyakran személyes kommentárokkal füszerezett felvételek pedig általában igen hamar elérhetővé válnak az érdeklődők számára. A sokszor tökéletlen, életlen vagy éppen mozgó felvételek egy „mintha én is ott lennék” érzést keltenek a nézőben, erősítve a személyes bevonódást, érzelmi reagálást (ahogy történt ez a rendőrségi intézkedést és George Floyd minneapolisi afroamerikai férfi haláltusáját végigkövető felvétel esetében is).

41 Ashley K. Farmer - Ivan Y. Sun: Citizen journalism and police legitimacy: Does recording the police make difference? In Mathieu Deflem (ed.): Sociology of crime, law and deviance. Emerald, 2016. 239-256.

42 Ashley K. Farmer - Ivan Y. Sun - Brian Chad Starks: Willingness to record police-public encounters: The impact of race and social and legal consciousness. Race and Justice, 5. (2015), 4. 356-377. 
Az ilyen vitatott rendőri intézkedéseket tartalmazó felvételek általában nagy érzelmi erővel rendelkeznek, mély nyomot hagynak a felvétel megtekintőjében, és képesek akár jelentősen is megváltoztatni, esetleg kifejezetten rontani is a rendőrség publikus imázsát. ${ }^{43}$ Mivel az intézkedést végzők nem, vagy csak igen kis mértékben tudják kontrollálni a felvétel tényét, módját, és csak nagyon korlátozott hatással lehetnek további útjára, nem meglepő, hogy a rendőri intézkedések állampolgári rögzítését és megosztását nem fogadta kitörő öröm a hatóságok részéről, és a helyzettel megbirkózni kénytelen rendőrség rendkívül konfliktusos viszonyba kerültt ${ }^{44}$ ezzel az újfajta láthatósággal.

A felmerülő kifogások sok esetben jogosak, hiszen a hirtelen passzív járókelőből megfigyelővé, egy esemény rögzítőjévé váló állampolgár sok esetben akadályozza magát az eljárás lefolytatását, figyelemelterelő lehet, biztonsági kockázatot okozhat, csökkentheti a békés kimenetel valószínűségét, a nyomozás számára hátrányos információkat oszthat meg másokkal, és felmerülhetnek az áldozatok védelmével kapcsolatos aggályok is.

A felvételek elterjedése előtt a rendőri intézkedések hagyományosan kevés szemtanú előtt, szinte csak az érintettek jelenlétében, és szinte megkérdőjelezhetetlen rendőri legitimációval, pontosan visszanézhető és értelmezhető dokumentáció nélkül zajlottak. Az új típusú környezetben a rendőri intézkedés rögzítésének valószínűsége rendkívül megemelkedett, s az intézkedő rendőr kevés hatással van arra, hogy tevékenységét ki és milyen attitűddel, verbális kommentekkel rögzíti. Nemcsak a mindig múködő testkamerák és publikus kamerák, hanem az éppen arra járó járókelők, vagy éppen maguk az eljárás alá vontak is rögzíthetik az eseményeket, újabb és újabb látószögeket adva az esemény dokumentálásához.

Az események rögzítése - mintegy Hawthorne-effektust generálva ${ }^{45}$ - pedig magát a megfigyelés tárgyát is megváltoztathatja. Ha a résztvevők biztosan tudják, hogy viselkedésükről filmfelvétel készül, és az adott esemény már nemcsak a jelenben, hanem egy elképzelhető jövőben is játszódik, ahol a felvételeket később visszajátszhatják és értelmezhetik (például egy rendőrségi vizsgálat vagy éppen egy bírósági tárgyalás során), akkor viselkedésüket e későbbi szcenárió figyelembevételével módosíthatják: vagyis a kamerák jelenlétében máshogy viselkednek. A felvétel ugyanis kiemeli az adott eseményt annak szociokognitív narratívájából, térbeli-időbeli kontextusából. ${ }^{46}$ A gyakran veszélyes helyzetben, igen nagy sebességgel zajló, akcióigényes folyamatok közben hozott rendőri döntésekről és intézkedési eseményekről készült felvéteket pedig más környezetben (például egy vizsgálat során), más értelmezési keretben, más érzelmi helyzetben dolgozzák fel. A kilassított, kinagyított ké-

\footnotetext{
3 Farmer (2016) i. m.

44 „[H] ave icreasingly fraught relationship with visibility.” Kevin D. Haggerty - Ajay Sandhu: The police crisis of visibility. IEEE Technology \& Society Magazine, 33. (2014), 2. 9.

45 Mayo, idézi: Klein Sándor: Munkapszichológia. Budapest, EDGE 2000, 2004.

46 Michalis Lianos: The new social control: The institutional web, normativity and the social bond. Ottawa, Red Quill Books Ltd. 2012.
} 
peken minden látszik, minden kivehető, de az alaphelyzet okozta érzelmi feszültség nélkül.

Adatok szerint a rendőrök eltérően vélekednek a láthatóságról aszerint, hogy „hivatalos” és „nem hivatalos” forrás kívánja megörökíteni az eseményeket. ${ }^{47}$ A saját szervezet vagy a hivatalos surveillance kamerák általi rögzítés sokkal kisebb ellenállást vált ki, mint a magánemberek vagy civil csoportok által történő felvétel. A rendőrök bíznak abban, hogy a hivatalos kamerafelvételek nem kerülnek illetéktelen kezekbe, nem lesznek láthatóak civilek számára különféle szociális médiafelületeken, míg a magánemberek által készített felvételek esetében erre nem számítanak, vagy nem feltétlenül hisznek a felvételek megfelelő kezelésében. Sokszor megfigyelhető, hogy a rendőrök aggódnak, hogy a felvételeket rosszul értelmezik a civil megtekintők, akik sem a helyzettel, sem pedig egyéb szakmai kérdésekkel nincsenek tisztában, és mindez rájuk és a rendőrségre is rossz fényt vet.

A rendőri munka állampolgári rögzítésével, a megfigyelői szerepet felvevő állampolgárokkal szemben tehát meglehetősen nagy az ellenállás, erős az érzelmi reakció.

A sousveillace felvételeket készítők elsősorban személyes tapasztalataik, az adott helyzetre vonatkozó attribúcióik, negatív érzelmeik és aggodalmaik miatt válnak megfigyelővé. A megfigyelti szereppel újonnan megbirkózni kénytelen rendőrök pedig nemcsak a megfigyeltség, hanem a felvételek okozta egyéb hatásokkal is kénytelenek megküzdeni.

\section{4. Összefoglalás}

A felügyeleti társadalomban a megfigyelti/megfigyelői szerepek sokkal átjárhatóbbá, felcserélhetőbbé váltak. A szerepek közti - korlátozott - átmenet, átfedés már a nem digitális korszakban is megjelent, de igazán kifejezetté a 21. században vált, ezzel jelentős társadalmi nyomást fejtve ki a hatalom gyakorlóira, a rendvédelemben dolgozókra (is).

A modern IKT-eszközök, számítástechnikai lehetőségek az eddig kevés megfigyelési lehetőséggel rendelkező állampolgárok számára is megnyitotta az utat a számukra fontos események rögzítése és megosztása felé kialakítva ezzel a civil journalism jelenségét, amelyben a rendőri tevékenység megfigyelése és dokumentálása is kiemelt szerepet kapott.

A rendőri munka így kialakuló új láthatósága kihívások elé állítja a rendőrség szervezetét és munkatársait, de új lehetőségeket is teremt a köz sikeresebb szolgálatára, a jobb feladat-végrehajtásra, a transzparensebb múködésre.

47 Haggerty-Sandhu (2014) i. m. 


\section{IRODALOMJEGYZÉK}

Balla József: Integritási kockázatok csökkentése a határrendészek körében. Integritás tanulmányok 10. Budapest, Nemzeti Közszolgálati Egyetem, 2019. Online: https://nkerepo.uni-nke.hu/ xmlui/bitstream/handle/123456789/15015/Hatarrendeszet_korrupcio_2019.pdf?sequence $=1$

Erdeiné Késmárki-Gally Szilvia - Erdei Attila - Grotte Judit: A biztonság szerepe a kötöttpályás közösségi közlekedésben Budapest agglomerációjában. Belügyi Szemle, 68. (2020), 11. 89104. Online: https://doi.org/10.38146/BSZ.2020.11.6

Esterházy Péter: Javított kiadás - Melléklet a Harmonia Caelestishez. Budapest, Magvető, 2002.

Farmer, Ashley. K. - Ivan Y. Sun - Brian Chad Starks: Willingness to record police-public encounters: The impact of race and social and legal consciousness. Race and Justice, 5. (2015), 4. 356377. Online: https://doi.org/10.1177/2153368715581663

Farmer, Ashley. K. - Ivan. Y. Sun: Citizen journalism and police legitimacy: Does recording the police make difference? In Mathieu Deflem (ed.): Sociology of crime, law and deviance. Emerald, 2016. 239-256. Online: https://doi.org/10.1108/S1521-613620160000021013

Farmer, Ashley. K.: Copwatchers: Citizen journalism and the changing police-community dynamic. $\mathrm{PhD}$ dissertation. University of Delaware, 2016. Online: https://udspace.udel.edu/bitstream/ handle/19716/19904/2016_FarmerAshley_PhD.pdf?sequence=1\&isAllowed=y

Ganascia, Jean-Gabriel: The generalized sousveillance society. Social Science Information, 49. (2010), 3. 489-507. Online: https://doi.org/10.1177/0539018410371027

Haggerty, Kevin D. - Ajay Sandhu: The police crisis of visibility. IEEE Technology \& Society Magazine, 33. (2014), 2. 9-12. Online: https://doi.org/10.1109/mts.2014.2319912

Héder Klára: „Figyelés vagy megfigyelés?” egy fogalom konceptualizációs kérdései. In Baráth Noémi Emőke - Mezei József (szerk.): Rendészet-tudomány-aktualitások: A rendészettudomány a fiatal kutatók szemével. Konferenciakötet. Budapest, Doktoranduszok Országos Szövetsége Rendészettudományi Osztály, 2019. 115-125. Online: www.dosz.hu/files/rende\%CC\%81szet-tudoma\%CC\%81ny-aktualitasok.pdf

Kies, Marianne F.: Policing the police: Freedom of the press, the right to privacy, and civilian recordings of police activity. The George Washington Law Review, 80. (2011), 1. 274-310. Online: www. gwlr.org/wp-content/uploads/2014/11/80-1-Kies-1.pdf

Klein Sándor: Munkapszichológia. Budapest, EDGE 2000, 2004.

Konrád György: Ha lehallgatnak. ÉS publicisztika, (1998), 24. Online: www.es.hu/old/Evergrns/ dox/TH.htm

Lévay Gábor: OSINT (Open Source Intelligence) - Nyílt információs hírszerzés. Budapest, Zrínyi Miklós Nemzetvédelmi Egyetem, 2006.

Lianos, Michalis: The new social control: The institutional web, normativity and the social bond. Ottawa, Red Quill Books Ltd., 2012.

Lyon, David: The Electronic eye: The rise of surveillance society. University of Minnesota Press, 1994.

Lyon, David: Surveillance society: Monitoring everyday life. Buckingham, Open University Press, 2001 Lyon, David: Surveillance studies: An overview. Cambridge, UK, Polity, 2007.

Mann, Steve - Jason Nolan - Barry Wellman: Sousveillance: Inventing and using wearable computing devices for data collection in surveillance environments. Surveillance \& Society, 1. (2002), 3. 331-355. Online: https://doi.org/10.24908/ss.v1i3.3344

Marwick, Alice E.: The public domain: Social surveillance in everyday life. Surveillance \& Society, 9. (2012), 4. 378-393. Online: https://doi.org/10.24908/ss.v9i4.4342

Miller, Serena: Citizen journalism. In M. Karlsson - H. Örnebring - M. Carlson - Y. Chan S. Craft - H. Sjøvaag - H. Wasserman (eds.): Oxford research encyclopedia of communication. New York, Oxford University Press, 2019. 1-25. Online: https://doi.org/10.1093/acrefore/9780190228613.013.786 
Murakami Wood, David - Kristie Ball (eds.): A Report on the surveillance society. Summary Report, Wilmslow, Office of the Information Commissioner, 2006. Online: https://ico.org.uk/ media/1042391/surveillance-society-summary-06.pdf

Országgyưlési Őrség: Adatkezelési tájékoztató az Országgyủlési Örség által alkalmazott testkamerával megvalósuló adatkezelési tevékenységről. é. n. Online: www.orszaggyulesiorseg.hu/documents/126480/1724451/testkamera_tajekoztato_2019.pdf/aeb5bfcc-7c19-5568-7cf1$0317 \mathrm{fc} 05 \mathrm{e} 543$

Örnebring, Henrik: Anything you can do, I can do better? Professional journalism on citizen journalism in six European countries. International Communication Gazette, 75. (2013), 1. 3553. Online: https://doi.org/10.1177/1748048512461761

Stanley, Jay - Barry Steinhardt: Bigger monster, weaker chains: The growth of American surveillance society. Washington, Technology and Liberty Program, American Civil Liberties Union, 2003. Online: www.aclu.org/report/bigger-monster-weaker-chains-growth-american-surveillance-society

Székely Iván: Surveillance - a megfigyeléstől a megfigyelő társadalmakig és a megfigyeléstudományig. Replika, 89. (2014), 5. 7-13. Online: http://real.mtak.hu/110328/1/89_01_Szekely.pdf

Thomsen, Frej Klem: The concepts of surveillance and sousveillance: A critical analysis. Social Science Information, 58. (2019), 4. 701-713. Online: https://doi.org/10.1177/0539018419884410

\section{Levéltári források}

ÁBTL 4.1. A-3114 - Az ügynökség vezetése és nevelése. Belügyminisztérium, III/I. Csoportfőnökség kiadványa, 1971.

ÁBTL - 3.1.2 - M-28327_1 „Bodo” fn. ügynök munkadossziéja, Budapest, Állambiztonsági Szolgálatok Történeti Levéltára

ÁBTL - 3.1.2 - M-28500_1 „Váraljai” fn. ügynök munkadossziéja, Budapest, Állambiztonsági Szolgálatok Történeti Levéltára

ÁBTL, M-17764_2 „Orvos” fn. ügynök munkadossziéja, Budapest, Állambiztonsági Szolgálatok Történeti Levéltára

\section{Egyéb források}

Ács Péter. In Varga Ágota: A tartótiszt. (dokumentumfilm) 2013. 30.09-30.32 perc

Kisfaludy András: Törvénytelen Muskátli. (dokumentumfilm) 1. rész, 1996. Online: www.youtube. $\mathrm{com} /$ watch?v=k3_HImimJh0\&t=839s 


\section{ABSTRACT}

The Subjective Aspects of Surveillance and Sousveillance

Klára HÉDER

In the "surveillance society", expanding the possibility of systematic, structured data collection can change the attitudes of observers, and the subjective experiences of observation. The study addresses the subjective aspects of surveillance, as well as the emotional issues and effects of the perceptual shift caused by the oscillation between the two roles, with particular reference to "civilian journalism" and police responses.

Keywords: information society, surveillance, sousveillance, subjective experience 